International Research Journal of Management, IT \& Social Sciences
Available online at https://sloap.org/journals/index.php/irjmis/
Vol. 6 No. 3, May 2019, pages: 70 82
ISSN: 2395-7492
https://doi.org/10.21744/irjmis.v6n3.634

\title{
Effect of Emotional and Spiritual Intelligence on Transformational Leadership and Impact on Employee Performance
}

Putu Harry Krisnanda ${ }^{a}$ Ida Bagus Ketut Surya ${ }^{\text {b }}$

Article history:

Received: 27 December 2018

Accepted: 31 March 2019

Published: 16 May 2019

\section{Keywords:}

emotional intelligence; employee performance; leadership; spiritual intelligence; transformational;

\begin{abstract}
The population of this research is all operator employees of PT. Gas Station Pratama Anugrah Dewata who is an employee with contract status. The sampling technique used in this study is saturated sampling or census with the research instrument using a questionnaire. Because the population is relatively small, all populations are used as samples, so the number of samples in this study were 40 operator employees of PT Gas Station Pratama Anugrah Dewata. Data were then analyzed using path analysis and Sobel test. The results showed that emotional intelligence and spiritual intelligence had a positive and significant effect on transformational leadership, emotional intelligence, spiritual intelligence and transformational leadership positive and significant effect on employee performance, and transformational leadership was able to mediate the effect of emotional intelligence and spiritual intelligence variables on the performance of PT Gas Station Pratama Anugrah Dewata operator employees.
\end{abstract}

2395-7492@ Copyright 2019. The Author. This is an open-access article under the CC BY-SA license (https://creativecommons.org/licenses/by-sa/4.0/) All rights reserved.

\section{Author correspondence:}

Putu Harry Krisnanda,

Faculty of Economic and Business of Udayana University, Bali, Indonesia.

Email address: harykrisnanda@gmail.com

\section{Introduction}

The ability of leaders is very important to run the organization. A good leader, he argues, can work in any form of structure. Transformational leadership style is expected to be a solution to overcome these problems so that they are able to realize company goals and are also expected to be able to improve employee performance. Research conducted by Supriyanto \& Troena (2012), shows that transformational leadership has a positive and significant effect on performance. Mondiani (2012), obtained the results of transformational leadership has a positive effect on employee performance variables.

Robbins \& Judge (2008), suggested that transformational leadership styles inspired their followers to exclude their personal interests for the good of the organization and they were able to have a tremendous effect on their followers.

\footnotetext{
a Faculty of Economic and Business, Udayana University, Bali, Indonesia ${ }^{\mathrm{b}}$ Faculty of Economic and Business, Udayana University, Bali, Indonesia
} 
Applying a transformational leadership style will be greatly effected by factors within a leader, there are many things that can affect it, including the intelligence possessed by the leader.

Emotional Quotient $(E Q)$ is intelligence in controlling emotions, how one realizes when his emotions react with certain conditions and situations. Based on the results of the initial interview with 3 SPBU operators related to emotional intelligence found a phenomenon or problem that the leader is still less able to handle the emotions of his employees. Leaders also sometimes allow the occurrence of disputes between employees, and leaders are also considered less capable of dealing with employee emotions related to regulations and policies decided.

Based on this phenomenon, emotional intelligence is part of the power of the leader who begins to believe its usefulness. Leaders must be able to develop emotional intelligence. Emotional intelligence is the ability to control, understand and effectively apply emotional strength and sharpness as a source of energy, information, and effect in managing the organization so that it can contribute to the achievement of set goals.

Improving employee performance is needed by leaders who are intelligent in all respects. Research conducted by Putra (2012), shows the results that emotional intelligence has a positive and significant effect on transformational leadership at PT Bank Danamon, Panglima Polim branch office. Burkham (2010), findings from this study indicate that leaders can develop and strengthen emotional intelligence and in doing so can be more likely to show the use of transformational leadership behaviors (Hidayat \& Budiatma, 2018; Yunita \& Saputra, 2019).

Spiritual intelligence (SQ) is intelligence to place our behavior and life in the context of broader and richer meanings, intelligence to judge that a person's actions or way of life are more meaningful than others (Zohar \& Marshall, 2000). SQ is the foundation needed to effectively function IQ and EQ. In fact, according to him, SQ is the highest intelligence of humans. Spiritual intelligence provides human morals, adaptability based on experience and love and equal abilities. SQ is about a holistic approach to life: usability, self-awareness, compassion, creativity, thinking skills, the ability to excuse others and others together.

Leaders with high SQ will usually recover faster from an illness, both physically and mentally. It is easier to rise from a fall or suffering, more resistant to stress, easier to see opportunities because it has a positive mental attitude, and is more cheerful, happy and satisfied in living life. Unlike leaders who have low SQ. In leaders with low SQ, success in terms of career, employment, income, status and many more things that are material in nature are not always able to make him happy. The results of the study from Gieseke (2014), show that spiritual intelligence has a positive and significant effect on transformational leadership. Supriyanto \& Troena (2012), show that spiritual intelligence has a positive and significant effect on transformational leadership.

These intelligence must not only be owned by a leader but must also be owned by all employees, because with these intelligence employees will be able to work better so that later they will be able to improve their performance and contribute more to the company. Research conducted by Rahmasari (2012), shows that emotional intelligence variables have a significant and positive effect on employee performance. Paisal \& Anggraini (2010), explained that spiritual intelligence partially had a positive and significant effect on employee performance at LBPP-LIA Palembang. Spiritual intelligence has more effect on employee performance than emotional intelligence because it has a greater regression coefficient. Sholiha et al., (2017), found that spiritual intelligence that has indicators of self-recognition, self-control, motivation, empathy and social skills affects the performance of Bululawang An-Nur Middle School teachers.

Transformational leadership style is expected to be able to bridge and explore and develop these intelligence not only for leaders but for all employees. Support from this intelligence will greatly help leaders and all employees to realize a better transformational leadership style and be able to improve the performance of all employees. As the results of research conducted by Dyan (2010), get results namely simultaneous transformational leadership and emotional intelligence significantly affect employee performance at PT Petrokimia Gresik with a calculated F value of 18.974 and Ftable of 3.15. Priyambodo (2012), found that transformational leadership managers mediate a positive relationship between the manager's emotional intelligence and employee performance. With their intelligence, humans can continue to maintain and improve the quality of their lives that are increasingly complex, through the process of thinking and learning continuously (Wiguna \& Yadnyana, 2019; Widiani \& Wirajaya, 2019).

\section{Literature Review}

\section{The Effect of Emotional Intelligence on Transformational Leadership}

Lily (2013), explained that there was a strong significant relationship between emotional intelligence and transformational leadership practiced by the Middle School Principal in Johor Bahru. Burkham (2010), findings from this study indicate that leaders can develop and strengthen emotional intelligence and in doing so can be more likely

Krisnanda, P. H., \& Surya, I. B. K. (2019). Effect of emotional and spiritual intelligence on transformational leadership and impact on employee performance. International Research Journal of Management, IT and Social Sciences, 6(3), 70-82. https://doi.org/10.21744/irjmis.v6n3.634 
to show the use of transformational leadership behaviors. Based on the results of previous studies, hypotheses can be formulated, namely:

H1: Emotional Intelligence has a positive and significant effect on Transformational Leadership

\section{The Effect of Spiritual Intelligence on Transformational Leadership}

The results of the research conducted by Supriyanto \& Troena (2012), show that spiritual intelligence has a positive and significant effect on transformational leadership. This result means that the better the level of spiritual intelligence, the better transformational leadership will be. Positive path coefficients indicate the increasing level of spiritual intelligence, it will lead to better transformational leadership. Similar research conducted by Muhdar \& Rahma (2015); Esfahani \& Motamenfar (2015); Alam (2014), obtained results that there was a positive and significant relationship between spiritual intelligence and transformational leadership. Based on the results of previous studies, hypotheses can be formulated, namely:

H2: Spiritual Intelligence has a positive and significant effect on Transformational Leadership

\section{The Effect of Emotional Intelligence on Employee Performance}

Rexhepi \& Berisha (2017), explain that in Macedonia the success of managing change depends on the level of emotional intelligence. There is a significant correlation between EQ level and management change index. The results of the research were Gunu \& Oladepo (2014), namely, there was a significant relationship between employees, emotional intelligence, organizational commitment, and employee performance. Notoprasetio (2012), also obtained the results of research, namely emotional intelligence (EQ) and a significant and positive effect on auditor performance. It can be said that the better the emotional intelligence possessed by an accountant, can have a significant effect and can produce a good performance as well, and vice versa. Similar results were also obtained by Jaya et al., (2012), emotional intelligence has a positive effect on employee performance at the Office of the Ministry of Religion, Karawang Regency. Based on the results of previous studies, hypotheses can be formulated, namely:

H3: Emotional Intelligence has a positive and significant effect on Employee Performance

\section{The Effect of Spiritual Intelligence on Employee Performance}

The results of the study from Paisal \& Anggraini (2010), explained that spiritual intelligence partially had a positive and significant effect on employee performance at LBPP-LIA Palembang. Spiritual intelligence has more effect on employee performance than emotional intelligence because it has a greater regression coefficient. Sholiha et al., (2017) found that spiritual intelligence that has indicators of self-recognition, self-control, motivation, empathy and social skills affects the performance of Bululawang An-Nur Middle School teachers. Anasrulloh (2015) obtained results namely the direct effect of spiritual intelligence on teacher performance resulting in a coefficient of 0.550 , indicating that teacher performance was effect by spiritual intelligence, the contribution size was 55\%. Cipta (2009), found that spiritual intelligence has a significant effect on employee performance. Based on the results of previous studies, hypotheses can be formulated, namely:

H4: Spiritual intelligence has a positive and significant effect on Employee Performance

\section{Effect of Transformational Leadership on Employee Performance}

The results of the study obtained by Schaubroeck et al., (2007), the effect of transformational leadership on team potential is moderated by team strength. Team collectivism shows a better positive effect of transformational leadership on team potential. Braun et al., (2013) positively related to employee job satisfaction at the level of individual and team analysis and objective team performance. Wang et al., (2011), transformational leadership has a positive impact on team performance and for each level of the organization. The results of a similar study were also obtained by Schaubroeck et al., (2011), the effect of leader behavior on team performance is fully mediated through trust in leader variables and the psychological state of the team. The service of leaders explains an additional $10 \%$ of the variance in team performance outside the effect of transformational leadership. Ozaralli (2003), found that transformational leadership contributed to the prediction of subordinate empowerment and that the more team members experienced team empowerment, the more effective the team was. Based on the results of previous studies, hypotheses can be formulated, namely:

H5: Transformational Leadership has a positive and significant effect on Employee Performance 
The Role of Transformational Leadership in Mediating the Effects of Emotional Intelligence on Employee Performance

The results of research by Mandala (2016); Rahmasari (2012); Notoprasetio (2012); Jaya et al., (2012), state that there is a significant effect between emotional intelligence on performance. This shows that the better emotional intelligence possessed by an employee can have a significant effect and can produce a good performance, and vice versa. Then the research conducted by Schaubroeck et al., (2007); Braun et al., (2013); Wang et al., (2011); Schaubroeck et al., (2011); Ozaralli (2003), his findings show that transformational leadership contributes to the prediction of subordinate empowerment and that the more team members experience team empowerment, the more effective the team will be. In other words, transformational leadership has a positive and significant effect on the performance of its employees. Based on these studies it can be concluded that if employees have the emotional intelligence that is supported by good empowerment by a leader, it will be able to produce better performance. Based on the results of previous studies, hypotheses can be formulated, namely:

H6: Transformational Leadership Mediates the effect of Emotional Intelligence on Employee Performance.

The Role of Transformational Leadership in Mediating the Effects of Spiritual Intelligence on Employee Performance

The results of the study by Paisal \& Anggraini (2010); Sholiha et al., (2017); Anasrulloh (2015); and Cipta (2009), state that there is a significant effect between spiritual intelligence on performance. This shows that the better spiritual intelligence possessed by an employee, can have a significant effect and can produce a good performance in an organization, and vice versa. Then the research conducted by Schaubroeck et al., (2007), Braun et al., (2013); Wang et al., (2011); Schaubroeck et al., (2011) and Ozaralli (2003), his findings show that transformational leadership contributes to the prediction of subordinate empowerment and that the more team members experience team empowerment, the more effective the team will be. In other words, transformational leadership has a positive and significant effect on the performance of its employees. Based on the research, it can be concluded that if employees have good spiritual intelligence then supported by good empowerment by a leader, it will be able to produce better performance. Based on the results of previous studies, hypotheses can be formulated, namely:

H7: Transformational Leadership Mediates the effect of Intellectual Intelligence on Employee Performance.

\section{Materials and Methods}

The population in this study were employees of PT Gas Station operators. Pratama Anugrah Dewata who is an employee with contract status. The sampling technique in this study is saturated sampling, which is that all members of the population are sampled because the population is relatively small, so all populations are used as samples, so the number of samples in this study is 40 employees. Path analysis is used to analyze the relationship between variables with the aim of knowing the direct or indirect effects, a set of independent variables (exogenous) on the dependent variable (endogenous). The path analysis model is a pattern of causal relationships or a set of hypothesized causal relations among the variables (Ridwan \& Engkos, 2008).

\section{Results and Discussions}

\subsection{Path Analysis}

Calculation of path coefficients is done using SPSS 18.0 for Windows software, and the results obtained are shown in Table 1 below:

Table 1

Path Analysis I

\begin{tabular}{|c|c|c|c|c|c|}
\hline \multirow[t]{2}{*}{ Variable } & \multicolumn{2}{|c|}{ Unstandardized Coefficients } & $\begin{array}{c}\text { Standardized } \\
\text { Coefficients }\end{array}$ & \multirow[t]{2}{*}{$\mathrm{t}$ value } & \multirow[t]{2}{*}{ Sig. } \\
\hline & B & Std. Error & Beta & & \\
\hline (Constant) & 2,560 & 1,446 & & 1,771 & 0,085 \\
\hline Emotional intelligence & 0,196 & 0,067 & 0,361 & 2,953 & 0,005 \\
\hline
\end{tabular}

Krisnanda, P. H., \& Surya, I. B. K. (2019). Effect of emotional and spiritual intelligence on transformational leadership and impact on employee performance. International Research Journal of Management, IT and Social Sciences, 6(3), 70-82. https://doi.org/10.21744/irjmis.v6n3.634 
Spiritual intelligence

0,493

0,110

0,551

4,500

0,000

Primary Data, 2018

Based on the results of the analysis of substructure 1 pathways as presented in Table 5.9, structural equations can be made as follows:

$$
\mathrm{Y} 1=0.196 \mathrm{X} 1+0.493 \mathrm{X} 2
$$

Regression coefficient values of emotional intelligence and spiritual intelligence are positive with a significance value of t-test less than 0.05 . This shows that all independent variables namely emotional intelligence (X1), and spiritual intelligence (X2), have a significant positive effect on transformational leadership variables (Y1).

Table 2

Path Analysis II

\begin{tabular}{|c|c|c|c|c|c|}
\hline \multirow[t]{2}{*}{ Variable } & \multicolumn{2}{|c|}{ Unstandardized Coefficients } & \multirow{2}{*}{$\begin{array}{c}\begin{array}{c}\text { Standardized } \\
\text { Coefficients }\end{array} \\
\text { Beta }\end{array}$} & \multirow[t]{2}{*}{ t value } & \multirow[t]{2}{*}{ Sig. } \\
\hline & $\mathrm{B}$ & Std. Error & & & \\
\hline (Constant) & 2,145 & 1,328 & & 1,615 & 0,115 \\
\hline Emotional intelligence & 0,162 & 0,065 & 0,261 & 2,477 & 0,018 \\
\hline Spiritual intelligence & 0,416 & 0,120 & 0,408 & 3,462 & 0,001 \\
\hline Transformational leadership & 0,374 & 0,145 & 0,329 & 2,581 & 0,014 \\
\hline
\end{tabular}

Primary Data, 2018

Based on the results of the analysis of substructure 2 pathways as presented in Table 5.10, structural equations can be made as follows:

$$
\mathrm{Y} 2=0.162 \mathrm{X} 1+0.416 \mathrm{X} 2+0.374 \mathrm{Y} 1
$$

Regression coefficient value of each independent variable is positive with a significance value of t-test less than 0.050 . This shows that all independent variables namely emotional intelligence (X1), spiritual intelligence (X2), and transformational leadership (Y1) have a significant positive effect on employee performance variables (Y2).

\subsection{Determination Coefficient (adjusted $R^{2}$ )}

The coefficient of determination essentially measures how far the model's ability to explain the variation of the dependent variable (Ghozali, 2016). In this statistical calculation, the value of $\mathrm{R}^{2}$ used is adjusted $\mathrm{R}^{2}$ because this is one indicator to determine the effect of adding one independent variable into one regression equation. The test results of the coefficient of determination in this study can be seen in full in Annex 6 which is summarized in Table 3 as follows.

Table 3

Determination Coefficient $\left(\mathrm{R}^{2}\right)$

\begin{tabular}{cccc}
\hline \multirow{2}{*}{ Structure } & \multicolumn{1}{c}{ Equation } & R Square & Adjusted R \\
Square
\end{tabular}

Primary Data, 2018

Table 3 shows the structural equation 1 (path analysis 1) the magnitude of the effect of independent variables on the dependent variable indicated by the value of determination (Adjusted R Square) of 0.690 means that $69 \%$ of the variation in transformational leadership at PT. Pratama Anugrah Dewata is effect by variations in emotional intelligence (X1) and spiritual intelligence (X2), while the remaining $31 \%$ is explained by other factors not included in the model. 
Whereas in structural equation 2 (path analysis 2) the magnitude of the effect of independent variables on the dependent variable indicated by the value of determination (Adjusted R Square) of 0.814 means that $81.4 \%$ variation in employee performance at PT. Pratama Anugrah Dewata is effect by variations in emotional intelligence (X1), spiritual intelligence (X2), and transformational leadership (Y1), while the remaining $18.6 \%$ is explained by other factors not included in the model.

Based on model 1 substructure and substructure 2, the final path diagram can be arranged. Before compiling the final path diagram model, the error standard value is calculated first:

$$
\begin{aligned}
& \mathrm{Pe}_{\mathrm{i}}=\sqrt{1-\mathrm{R}_{\mathrm{i}}{ }^{2}} \\
& \mathrm{Pe}_{1}=\sqrt{1-R_{1}{ }^{2}}=\sqrt{1-0,690}=0,557 \\
& \mathrm{Pe}_{2}=\sqrt{1-{R_{2}}^{2}}=\sqrt{1-0,814}=0,431
\end{aligned}
$$

Based on the calculation of the effect of error (Pei), the result of the effect of error (Pe1) is 0.557 and the effect of error $(\mathrm{Pe} 2)$ is 0.431 . The results of the total coefficient of determination are as follows:

$$
\begin{aligned}
\mathrm{R}^{2}{ }_{\mathrm{m}} & =1-\left(\mathrm{Pe}_{1}\right)^{2}\left(\mathrm{Pe}_{2}\right)^{2} \\
& =1-(0,557)^{2}(0,431)^{2} \\
& =1-(0,310)(0,186) \\
& =1-0,057=0,943
\end{aligned}
$$

The total determination value of 0.943 means that $94.3 \%$ of the variation in work performance is effect by variations in emotional intelligence, spiritual intelligence, and transformational leadership, while the remaining 5.7\% is explained by other factors not included in the model.

Based on the results of the analysis of lines 1 and 2 listed in Appendix 6 and summarized in Tables 1 and 2, the results of the path coefficients in this research hypothesis can be illustrated in Figure 1 as follows.

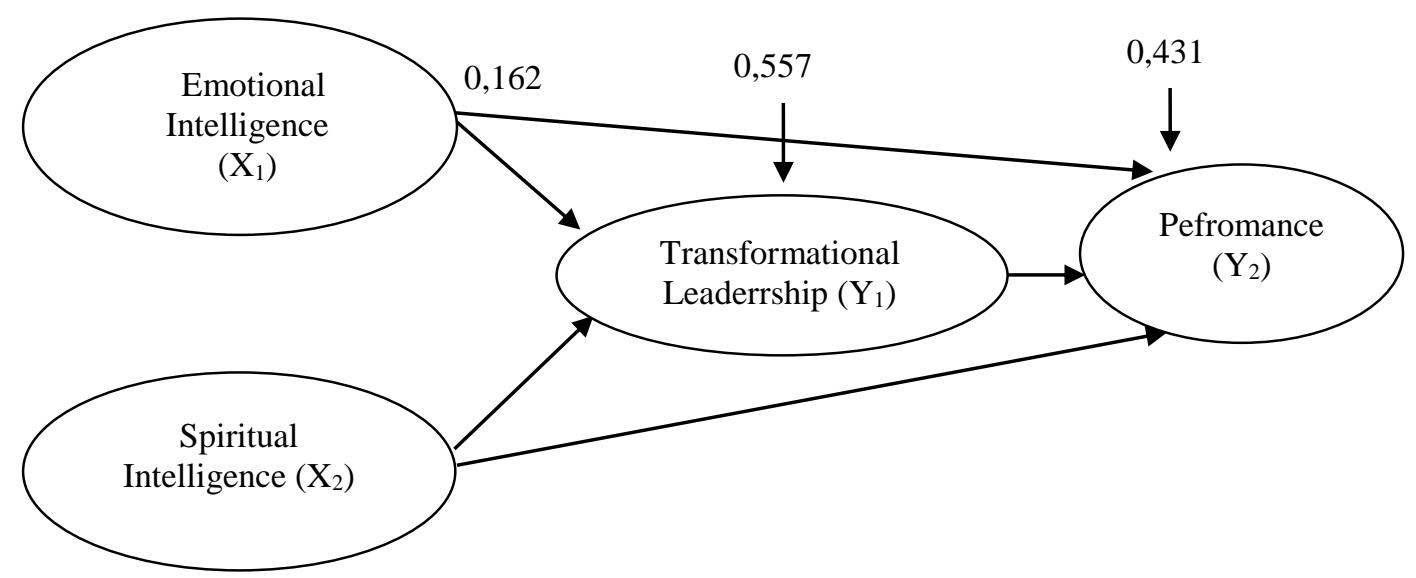

Figure 1. Path analysis model

Table 4

The direct, indirect and total effect

\begin{tabular}{cccc}
\hline Variable & Direct Effect & $(\mathrm{Y} 1)(\beta 1 \times \beta 3)$ & Total Effect \\
\hline $\mathrm{X}_{1} \rightarrow \mathrm{Y}_{1}$ & 0,196 & - & 0,196 \\
$\mathrm{X}_{1} \rightarrow \mathrm{Y}_{2}$ & 0,162 & $(0,196 \times 0,374)=0,073$ & 0,235 \\
$\mathrm{Y}_{1} \rightarrow \mathrm{Y}_{2}$ & 0,374 & - & 0,374 \\
$\mathrm{X}_{2} \rightarrow \mathrm{Y}_{1}$ & 0,493 & - & 0,493 \\
$\mathrm{X}_{2} \rightarrow \mathrm{Y}_{2}$ & 0,416 & $(0,493 \times 0,374)=0,184$ & 0,600 \\
\hline
\end{tabular}

Primary Data, 2018

Krisnanda, P. H., \& Surya, I. B. K. (2019). Effect of emotional and spiritual intelligence on transformational leadership and impact on employee performance. International Research Journal of Management, IT and Social Sciences, 6(3), 70-82. https://doi.org/10.21744/irjmis.v6n3.634 
The results of the analysis in Table 4 show that the direct effect of emotional intelligence on employee performance is 0.162 , then the direct effect of transformational leadership on employee performance is 0.374 , and the direct effect of spiritual intelligence on employee performance is 0.416 . This shows that the performance of employees at PT. Pratama Anugrah Dewata is more effect by transformational leadership variables than emotional or spiritual intelligence possessed by operator employees. This information illustrates that operator employees at PT. Pratama Anugrah Dewata will have a good performance if the company has good transformational leadership.

If reviewed based on indirect effect in Table 5.12 shows that the indirect effect of emotional intelligence variables on employee performance through transformational leadership has an effect of 0.073 , then added with a direct effect of 0.162 , then the total effect value is obtained at 0.235 . This means that if a company has employees with high emotional intelligence and added with a good transformational leadership style, then the employee's performance will increase.

The indirect effect of spiritual intelligence on employee performance through transformational leadership has an effect of 0.184 , then added with a direct effect of 0.416 , then the total effect value of 0.600 is obtained. This means that if a company has employees with high emotional intelligence and added with a good transformational leadership style, then the employee's performance will increase. Based on the explanation, it can be concluded that in general respondents will have more optimal performance, if they have high spiritual intelligence and are supported by a good transformational leadership style in the company.

\subsection{Sobel Test}

To test the significance of the indirect effect, the $\mathrm{z}$ value of the ab coefficient is calculated as follows:

$$
\begin{aligned}
S_{b 1 b 5} & =\sqrt{b 5^{2} S_{b 1}^{2}+b 1^{2} S_{b 5}^{2}+S_{b 1}^{2} S_{b 5}^{2}} \\
S_{b 1 b 5} & =\sqrt{(0,374)^{2}(0,067)^{2}+(0,196)^{2}(0,115)^{2}+(0,067)^{2}(0,115)^{2}} \\
S_{b 1 b 5} & =0,034573
\end{aligned}
$$

To test the significance of the indirect effect, calculate the $\mathrm{z}$ value of the coefficient ab with the following formula:

$$
\begin{aligned}
& Z=\frac{b 1 b 5}{S b 1 b 5} \\
& Z=\frac{(0,196)(0,374)}{0,034573} \\
& Z=2,1202(\operatorname{sig}=0,034)
\end{aligned}
$$

Because $\mathrm{Z}$ value is 2.1202> 1.96. This means that transformational leadership (Y1) is a variable that mediates emotional intelligence (X1) on employee performance (Y2) or in other words Emotional intelligence indirectly affects the employee performance of PT Gas Station. Pratama Anugrah Dewata through transformational leadership.

To test the significance of the indirect effect, the $\mathrm{z}$ value of the ab coefficient is calculated as follows:

$$
\begin{aligned}
S_{b 2 b 5} & =\sqrt{b 5^{2} S_{b 2}^{2}+b 2^{2} S_{b 5}^{2}+S_{b 1}^{2} S_{b 5}^{2}} \\
S_{b 2 b 5} & =\sqrt{(0,374)^{2}(0,110)^{2}+(0,493)^{2}(0,115)^{2}+(0,110)^{2}(0,115)^{2}} \\
S_{b 2 b 5} & =0,071182
\end{aligned}
$$

To test the significance of the indirect effect, calculate the $\mathrm{z}$ value of the coefficient ab with the following formula:

$$
\begin{aligned}
& =\frac{b 2 b 5}{S b 2 b 5} \\
& Z=\frac{(0,493)(0,374)}{0,071182} \\
& Z=2,5903(\operatorname{sig}=0,009) .
\end{aligned}
$$

Because $Z$ value is 2.5903> 1.96. This means that transformational leadership (Y1) is a variable that mediates spiritual intelligence (X2) on employee performance (Y2) or in other words spiritual intelligence indirectly affects the employee performance of PT Gas Station operators. Pratama Anugrah Dewata through transformational leadership. 


\subsection{The Effects of emotional intelligence on transformational leadership}

The results of the analysis in this study indicate that emotional intelligence has a positive and significant effect on transformational leadership. This means that the higher emotional intelligence, it will affect the increasing transformational leadership. Likewise, the lower the emotional intelligence possessed by a company leader, the more it will affect the decreasing transformational leadership style. Emotional intelligence is absolutely needed by a leader because armed with good emotional intelligence, the behavior, and behavior of the leader will automatically be controlled and protected from misconduct, so that the transformational leadership that is applied will be better.

This study supports some of the results of previous studies and is consistent with the results of research conducted by Chrusciel (2006); Singh \& Modassir (2007), and Yocum (2006), who found that emotional intelligence has a positive and significant effect on transformational leadership. The research indicates that high emotional intelligence will underlie the improvement of transformational leadership. The results of this study also support the findings of Lily (2013) and Burkham (2010), who found that there was a positive and significant influence between emotional intelligence on transformational leadership. This means that the higher emotional intelligence, the transformational leadership will increase.

\subsection{The Effect of spiritual intelligence on transformational leadership}

The results of the analysis in this study indicate that spiritual intelligence has a positive and significant effect on transformational leadership. This means that the higher the spiritual intelligence possessed by a leader will affect the increasing transformational leadership style. Vice versa, the lower the spiritual intelligence possessed by a leader will affect the decreasing transformational leadership style. Smart spiritual means having a high level of awareness in working full of dedication and responsibility. Leaders with spiritual awareness will foster a high sense of responsibility. Spiritual intelligence is very influential in transformational leadership. The increasing spiritual intelligence of a leader, the transformational leadership that is applied will be better.

This study supports some of the results of previous studies and is consistent with the results of Tan et al., (2013) and Gieseke (2014), who found that spiritual intelligence has a positive and significant effect on transformational leadership, namely increasing the level of spiritual intelligence, it will lead to better transformational leadership. The results of this study also support the findings of Supriyanto \& Troena (2012); Muhdar \& Rahma (2015); Esfahani \& Motamenfar (2015) and Alam (2014), which show that spiritual intelligence has a positive and significant influence on transformational leadership. This result means that the higher the level of spiritual intelligence, the better transformational leadership will be.

\subsection{The Effect of emotional intelligence on employee performance}

The results of the analysis in this study indicate that emotional intelligence has a positive and significant effect on employee performance. This means that the higher emotional intelligence, it will affect the increasing performance of employees. Likewise vice versa the lower the emotional intelligence that is owned it will affect the decline in employee performance. Leaders and employees who have high emotional awareness will be able to resist emotions and foster a high sense of responsibility so that the resulting performance becomes better.

This study supports some of the results of previous studies and is consistent with the results of research conducted by Mandala (2016) and Rahmasari (2012), who found that emotional intelligence has a positive and significant effect on employee performance. The study indicates that high emotional intelligence will encourage improvement in employee performance. The results of this study also support the findings of Notoprasetio (2012) and Jaya et al., (2012), who found that there was a positive and significant influence between emotional intelligence on employee performance. This means that the better emotional intelligence possessed by an employee will form or produce a good performance.

\subsection{The Effect of spiritual intelligence on employee performance}

The results of the analysis in this study indicate that spiritual intelligence has a positive and significant effect on employee performance. This means that the higher the spiritual intelligence possessed, the better the performance of employees will be. Likewise, vice versa, the lower the spiritual intelligence possessed it will affect the decreasing

Krisnanda, P. H., \& Surya, I. B. K. (2019). Effect of emotional and spiritual intelligence on transformational leadership and impact on employee performance. International Research Journal of Management, IT and Social Sciences, 6(3), 70-82. https://doi.org/10.21744/irjmis.v6n3.634 
performance of employees. The increasing spiritual intelligence of leaders and employees, the performance produced will also increase. High spiritual intelligence makes it easy for leaders and employees to carry out their profession meaningfully so that it has a major impact on improving performance. Spiritual intelligence is absolutely needed by leaders and employees because armed with good spiritual intelligence, the behavior, and behavior of leaders and employees will automatically be controlled and protected from reprehensible actions.

This study supports some of the results of previous studies and is consistent with the results of the study of Paisal \& Anggraini (2010) and Sholiha et al., (2017), produce better performance. The results of this study also support the findings of Anasrulloh (2015) and Cipta (2009), which show that spiritual intelligence has a positive and significant influence on employee performance. This result means that the higher the level of spiritual intelligence, the employee will be able to produce better performance.

\subsection{The Effect of transformational leadership on employee performance}

The results of the analysis show that transformational leadership has a positive and significant effect on employee performance. The better the transformational leadership style in the company will have an effect on the increasing performance of the employees of the operator at the PT Gas Station. Pratama Anugrah Dewata. Vice versa, the worse the transformational leadership style in the company will affect the decline in employee performance. A leader with a good transformational leadership style will focus on achieving the values, beliefs, attitudes, behaviors, emotions, and needs of his employees towards better change so that employees feel trust, admiration, loyalty and respect for leaders, and they are motivated to produce better performance.

This study is consistent and in accordance with the results of research conducted by Ozalli (2003), and Schaubroeck et al., (2007), who found results that transformational leadership had a positive and significant effect on employee performance. The results of this study also support the findings of Braun et al., (2013); Schaubroeck et al., (2011) and Wang et al., (2011), which state that transformational leadership has a positive impact on team performance and for each level of the organization. This indicates that transformational leadership contributes to the prediction of subordinate empowerment and that the more team members experience team empowerment, the more effective the team will be.

\subsection{The Role of Transformational Leadership in Mediating the Effects of Emotional Intelligence on Employee Performance}

Emotional intelligence that is formed in the employee will cause good things by obeying all applicable regulations in the organization and will achieve psychological maturity so that it can achieve maximum performance. The results of the analysis in this study indicate that transformational leadership is able to mediate the influence of emotional intelligence variables on the performance of employees of PT Gas Station operators. Pratama Anugrah Dewata. This means that employee performance will increase if employees have high emotional intelligence and get good direction from a leader with a good transformative leadership style.

This study supports the findings of Priyambodo (2012), who get results, namely transformational leadership variables significantly become partial mediation variables in the positive influence between EI and performance. In accordance with the results of the test, it shows that with a high level of emotional intelligence of managers and the application of transformational leadership in the company can improve employee performance. This indicates that transformational leadership style mediates a positive relationship between emotional intelligence and employee performance.

\subsection{The Role of Transformational Leadership in Mediating the Effects of Spiritual Intelligence on Employee Performance}

The results of the analysis in this study indicate that transformational leadership is able to mediate the influence of spiritual intelligence variables on the performance of employees of PT Gas Station operators. Pratama Anugrah Dewata. This means that employee performance will increase if employees have high spiritual intelligence and get good direction from a leader with a good transformative leadership style.

The results of this study are supported by the findings of Supriyanto \& Troena (2012), which state that spirituality awareness gives a leadership style that is very devout and humane, he will bring his organization towards the vision and mission of Godhead, not towards greed. Leaders with spiritual awareness will foster a high sense of responsibility. 
Spiritual intelligence is very influential in transformational leadership. Increasing the manager's spiritual intelligence, the transformational leadership that is applied will be better. Smart spiritual means having a high level of awareness in working full of dedication and responsibility. Increasing the manager's spiritual intelligence, the performance produced will also increase. High spiritual intelligence makes it easy for managers to carry out their profession meaningfully so that it has a major impact on improving the manager's performance. Spiritual intelligence is absolutely necessary by managers because armed with good spiritual intelligence, the behavior, and behavior of the leader will automatically be controlled and protected from misconduct.

A similar study conducted by Asmadi et al., (2015), Supriyanto \& Troena (2012), obtain results that the high level of Spiritual intelligence managers and the application of good transformational leadership in the company can improve employee performance. This indicates that transformational leadership style mediates a positive relationship between emotional intelligence and employee performance.

\section{Conclusion}

In an effort to improve emotional intelligence for the better, then the leader/manager of PT. Pratama Anugrah Dewata should always evaluate and improve the emotional intelligence that is owned in order to be able to handle the emotions of their employees.

In an effort to improve spiritual intelligence, the leader/manager of PT. Pratama Anugrah Dewata should try to be flexible in working. If the leader has a flexible attitude, the leader/manager will be able to make employees more comfortable and not work under pressure, so that the resulting performance will be better.

In an effort to improve transformational leadership for the better, the leader/manager of PT. Pratama Anugrah Dewata should be able to give attention to the career development of their employees. If employees feel cared for by their leaders and are given opportunities for career development, then employees will be motivated to work better for the company.

In an effort to improve employee performance, the management of PT. Pratama Anugrah Dewata should make strict sanctions for undisciplined employees, especially for employees whose attendance is low, so that employees feel deterred, and ultimately try to maximize attendance.

Research Limitations

This research was conducted in a small scope, namely at the PT gas station Pratama Anugrah Dewata only, so it would be better to take on a larger scope. Factors that influence employee performance in this study are emotional intelligence, spiritual intelligence, and transformational leadership, while there are many other factors that influence employee performance, such as work stress factors, work discipline, work environment, financial factors and other factors. This research is only carried out in a certain time point (cross section), while the environment changes at any time (dynamic) so that this research is important to do again in the future.

\section{Conflict of interest statement and funding sources}

The authors declared that they have no competing interest. The study was financed by personal funding.

Statement of authorship

The authors have a responsibility for the conception and design of the study. The authors have approved the final article.

\section{Acknowledgments}

The authors would like to acknowledge the editor of IRJMIS for their support, valuable time, and advice in completing the present article.

Krisnanda, P. H., \& Surya, I. B. K. (2019). Effect of emotional and spiritual intelligence on transformational leadership and impact on employee performance. International Research Journal of Management, IT and Social Sciences, 6(3), 70-82. https://doi.org/10.21744/irjmis.v6n3.634 


\section{References}

Alam, M. R. (2014). Predictability horizon of oceanic rogue waves. Geophysical Research Letters, 41(23), 8477-8485. http://dx.doi.org/10.1002/2014GL061214

Anasrulloh, M. (2015). Pengaruh Kecerdasan Spiritul Terhadap Kinerja Guru dan Motivasi Kerja Sebagai Variabel Intervening Di MTs Darul Hikmah Tulungagung. Dosen STKIP PGRI Tulungagung.

Anggraini, D., \& Faisal, F. (2010). Menentukan solusi optimal pada pemrograman linier dengan n fungsi objektif menggunakan solver metode simpleks. jurnal matematika murni dan terapan epsilon, 4(1), 13-30.

Asmadi, D., Syairudin, B., \& Widodo, E. (2015). Kontribusi Kecerdasan Emosional dan Kecerdasan Spiritual Terhadap Kinerja Karyawan yang dimoderasi Kepemimpinan Transformasional. In Prosiding Seminar Nasional Manajemen Teknologi XXII (pp. 1-10).

Boserup, E., Tan, S. F., \& Toulmin, C. (2013). Woman's role in economic development. Routledge.

Braun, S., Peus, C., Weisweiler, S., \& Frey, D. (2013). Transformational leadership, job satisfaction, and team performance: A multilevel mediation model of trust. The Leadership Quarterly, 24(1), 270-283. https://doi.org/10.1016/j.leaqua.2012.11.006

Burkham, A. B. (2010). The relationship of emotional intelligence and transformational leadership behavior in Texas AgriLife Extension Service mid-managers (Doctoral dissertation, Texas A \& M University).

Chrusciel, D. (2006). Considerations of emotional intelligence (EI) in dealing with change decision management. Management Decision, 44(5), 644-657. https://doi.org/10.1108/00251740610668897

Dyan S.C. (2010). Pengaruh Kepemimpinan Transformasional dan Kecerdasan Emosional Terhadap Kinerja Karyawan(Studi Pada Proyek Konversi Energi Batubara PT. Petrokimia Gresik). Tesis. Program Magister Manajemen Fakultas Ekonomi Universitas Brawijaya Malang.

Esfahani, S. T., \& MotamenFar, M. (2015). Relationship between spiritual intelligence and transformational leadership. WALIA journal, 31(S3), 187-196.

Fitriyani, D., Prasetyo, E., Mirdah, A., \& Putra, W. E. (2012). Pengaruh Manajemen Laba terhadap Kinerja Perusahaan dengan Kualitas Audit sebagai Variabel pemoderasi. Jurnal.

Ghozali, I. (2006). Aplikasi analisis multivariate dengan program SPSS. Badan Penerbit Universitas Diponegoro.

Gieseke, F., Heinermann, J., Oancea, C., \& Igel, C. (2014, January). Buffer kd trees: processing massive nearest neighbor queries on GPUs. In International Conference on Machine Learning (pp. 172-180).

Gunu, U., \& Oladepo, R. O. (2014). Impact of Emotional Intelligence on Employees' Performance and Organizational Commitment: A Case Study of Dangote Flour Mills Workers. University of Mauritius Research Journal, 20, 1-32.

Hidayat, R., \& Budiatma, J. (2018). Education and job training on employee performance. International Journal of Social Sciences and Humanities, 2(1), 171-181. https://doi.org/10.29332/ijssh.v2n1.140

Jaya, M. K., Mulyadi, D., \& Sulaeman, E. (2012). Pengaruh Kecerdasan Emosional Terhadap Kinerja Karyawan Pada Kantor Kementerian Agama Kabupaten Kerawang. Jurnal Manajemen, 10(1), 1038-1046.

Lily, S. (2013). The Relationship between Emotional Intelligence and Transformational Leadership of Secondary School Principals in Johor Bahru (Doctoral dissertation, Universiti Teknologi Malaysia).

Mandala, E. A. (2016). Pengaruh Kecerdasan Emosional Dan Kecerdasan Spiritual Pada Kepuasan Kerja Yang Berdampak Terhadap Kinerja (Studi Pada Karyawan PT. Madu Baru Bantul, Yogyakarta) (Doctoral dissertation, UII).

Marshall, I., \& Zohar, D. (2007). SQ: Memanfaatkan Kecerdasan Spiritual dalam Berfikir Integralistik dan Holistik untuk Memaknai Kehidupan.

Mondiani, T. (2012). Pengaruh kepemimpinan transformasional dan kompensasi terhadap kinerja karyawan PT. PLN (PERSERO) UPJ Semarang. Jurnal Administrasi Bisnis, 1(1).

Muhdar, H. M. (2015). The Influence of Spiritual Intelligence, Leadership, and Organizational Culture on Organizational Citizenship Behavior: A Study To Islamic Bank in Makassar City. Al-Ulum, 15(1), 135-156.

Notoprasetio, C. G. (2012). Pengaruh Kecerdasan Emosional dan Kecerdasan Spiritual Auditor terhadap Kinerja Auditor pada Kantor Akuntan Publik di Surabaya. Jurnal Ilmiah Mahasiswa Akuntansi, 1(4), 76-81.

Özaralli, N. (2003). Effects of transformational leadership on empowerment and team effectiveness. Leadership \& Organization Development Journal, 24(6), 335-344. https://doi.org/10.1108/01437730310494301

Priyambodo, T. K., \& Suprihanto, D. (2016). Information security on eGovernment as information-centric networks. Intl. J. Comput. Eng. Res. Trends, 3(35), 365.

Rahmasari, L. (2016). Pengaruh Kecerdasan Intelektual, Kecerdasan Emosi dan Kecerdasan Spiritual Terhadap Kinerja Karyawan. Majalah Ilmiah Informatika, 3(1). 
Rexhepi, G., \& Berisha, B. (2017). The effects of emotional intelligence in employees performance. International Journal of Business and Globalisation, 18(4), 467-479. https://doi.org/10.1504/IJBG.2017.084351

Ridwan, E. A. K. (2008). Cara Menggunakan dan Memakai Analisis Jalur (Path Analiysis). Bandung: Alfabeta.

Robbins, S. P., \& Judge, T. A. (2008). Perilaku organisasi (Organizational behavior). Jakarta: Salemba Empat.

Schaubroeck, J., Lam, S. S., \& Cha, S. E. (2007). Embracing transformational leadership: Team values and the impact of leader behavior on team performance. Journal of applied psychology, 92(4), 1020.

Schaubroeck, J., Lam, S. S., \& Peng, A. C. (2011). Cognition-based and affect-based trust as mediators of leader behavior influences on team performance. Journal of Applied Psychology, 96(4), 863.

Sholiha, M., Sunaryo, H., \& Priyono, A. A. (2017). Pengaruh Kecerdasan Emosional Dan Kecerdasan Spiritual Terhadap Kinerja Guru Smp An-Nur Bululawang-Malang. Jurnal Warta Ekonomi, 6(01).

Singh, T., \& Modassir, A. (2007). Relationship of emotional intelligence with transformational leadership and organizational citizenship behavior. IIM Bangalore Research Paper, (262).

Solihin, I. (2009). Corporate Social Responsibility: from charity to sustainability. Penerbit Salemba.

Supriyanto, A. S., \& Troena, E. A. (2012). Pengaruh Kecerdasan Emosional dan Kecerdasan Spiritual terhadap Kepemimpinan Transformasional, Kepuasan Kerja dan Kinerja Manajer (Studi di Bank Syari'ah Kota Malang)‘. Jurnal Aplikasi Manajemen, 10(4), 693-617.

Wang, G., Oh, I. S., Courtright, S. H., \& Colbert, A. E. (2011). Transformational leadership and performance across criteria and levels: A meta-analytic review of 25 years of research. Group \& organization management, 36(2), 223270. https://doi.org/10.1177\%2F1059601111401017

Widiani, N. P., Putri, A. M. A. D., Sari, M. M. R., \& Wirajaya, I. G. A. (2019). The effect of love of money and emotional intelligence on employee performance with organizational citizenship behavior as mediating variable. International Research Journal of Engineering, IT \& Scientific Research, 5(1), 39-49. https://doi.org/10.21744/irjeis.v5n1.596

Wiguna, I. P. I., \& Yadnyana, K. (2019). The role of working experience moderating the effect of emotional intelligence, intellectual intelligence, and spiritual intelligence on the ethical decision of tax consultants in Bali area. International Research Journal of Management, IT and Social Sciences, 6(3), 18-28. https://doi.org/10.21744/irjmis.v6n3.624

Yocum, R. (2007). The moderating effects of narcissism on the relationship between emotional intelligence and leadership effectiveness, moral reasoning and managerial trust (Vol. 68, No. 04).

Yunita, P. I., \& Saputra, I. G. N. W. H. (2019). Millennial generation in accepting mutations: Impact on work stress and employee performance. International Journal of Social Sciences and Humanities, 3(1), 102-114. https://doi.org/10.29332/ijssh.v3n1.268

Zohar, D., Marshall, I., \& Marshall, I. N. (2000). SQ: Connecting with our spiritual intelligence. Bloomsbury Publishing USA.

Krisnanda, P. H., \& Surya, I. B. K. (2019). Effect of emotional and spiritual intelligence on transformational leadership and impact on employee performance. International Research Journal of Management, IT and Social Sciences, 6(3), 70-82. https://doi.org/10.21744/irjmis.v6n3.634 


\section{Biography of Author}

\begin{tabular}{|l|l|}
\hline & Putu Harry Krisnanda was born on Denpasar. Currently as a supervisor at Denpasar \\
Office. He finished his study at Udayana Unversity. He interested in the human resource \\
field. \\
Email: harykrisnanda@gmail.com
\end{tabular}

